\title{
Peningkatan Akses Pendidikan oleh Baznas Kota Padang bagi Masyarakat Kurang Mampu Melalui Program Padang Cerdas
}

\author{
Dena Alesia, Nurman S \\ Program Studi Pendidikan Pancasila dan Kewarganegaraan \\ Universitas Negeri Padang \\ E-mail: dennaalezia@gmail.com
}

\section{ABSTRAK}

Tujuan dari penelitian ini adalah untuk mendeskripsikan pelaksanaan Program Padang Cerdas oleh BAZNAS Kota Padang, mengidentifikasi bentuk pendanaan Program Padang Cerdas serta melihat pemerataan akses dalam pelaksanaan Program Padang Cerdas. Penelitian ini menggunakan metode kualitatif dengan informan penelitian diantaranya Kepala Bidang Pendistribusian dan Pendayagunaaan BAZNAS Kota Padang, pihak sekolah, siswa penerima Beasiswa Padang Cerdas dan orang tua penerima Beasiswa Padang Cerdas. Metode pengumpulan data dalam penelitian ini terdiri dari observasi, wawancara dan dokumentasi. Hasil dari penelitian ini menunjukkan bahwa pelaksanaan program padang cerdas sudah berjalan semestinya seperti sosialisasi yang dilakukan oleh penyelenggara program padang cerdas sudah dijalankan, kemudian mengenai pemetaan target sudah sangat jelas. Dalam program Padang Cerdas memberikan kuota tiap sekolah sebanyak 5 orang. Setelah itu mengenai dana yang diterima oleh siswa sudah mencukupi dan sudah disesuaikan dengan kebutuhan yang diperlukan bagi siswa masing-masing tingkatan sekolah. Namun ada beberapa sekolah yang tidak terdaftar dalam program Padang Cerdas karena pihak sekolah tidak mengirimkan data siswa BAZNAS Kota Padang. Oleh karena itu dapat disimpulkan bahwa dalam pelaksanaan program padang cerdas telah dilaksanakan sebagaimana mestinya walaupun ada beberapa yang belum efektif.

Kata Kunci: akses pendidikan, BAZNAS, masyarakat kurang mampu, Program Padang Cerdas

\section{ABSTRACT}

The implementation of the Padang Pintar Program conducted by the National Amil Zakat Agency (BAZNAS) has not been fully implemented. Like there are still schools that are not registered in the Padang Pintar Program. The purpose of this research is to describe the implementation of the Padang Pintar program by the BAZNAS, identify the forms of funding for the Padang Pintar Program and look at equitable access to the implementation of the Padang Pintar Program. This study used a qualitative method with research informants including the Head of Distribution and Utilization of BAZNAS of Padang City, schools, students who received the Padang Pintar Scholarship and parents who received the Padang 
Pintar Scholarship. Data collection methods in this study consisted of observations, interviews and documentation. The results of this study indicate that the implementation of the smart field program has proceeded properly as the socialization carried out by the organizer of the smart field program has been carried out, then the mapping of targets is very clear. In the Padang Pintar program, each school is given a quota of 5 people. After that the funds received by students are sufficient and have been adjusted to the needs needed for students at each school level. It's just that there are some schools that are not registered in the smart pdang program because the school does not send student data to the BAZNAS of Padang City. in this case it can be concluded that in the implementation of the smart field program has been implemented as it should carry out the program even though there are some that have not been effective in its implementation.

Keywords : access to education, BAZNAS, poor people, Padang Pintar Program 


\section{PENDAHULUAN}

Penelitian mengenai Program Padang Cerdas menarik dan penting untuk diteliti karena program ini merupakan sebuah program beasiswa yang diberikan untuk anak yang tidak mampu serta memiliki prestasi. Melalui program ini iharapkan berguna untuk biaya pendidikan masyarakat dengan tingkat ekonomi yang rendah. sehingga masyarakat dapat terbantu dengan beasiswa Padang Cerdas ini. Biaya pendidikan yang dimaksud merupakan biaya yang telah mencakup seluruhnya dengan jenis pengeluaran yang berkaitan dengan penyelenggaraan pendidikan (Sinulingga, 2014). Mengingat kerentanan masalah pendidikan dengan faktor pembiayaan menjadi masalah yang sampai saat ini masih terjadi. Hal ini terjadi karena dunia pendidikan di Indonesia mengalami degradasi dengan pemaknaan pendidikan yang semakin marak dimana pendidikan dimaknai sebagai milik orang tertentu saja yakni hanya dinikmati oleh kalangan orang kaya (Sudarsana, 2016).

Penelitian terdahulu yang memiliki kesamaan dengan penelitian ini adalah penelitian yang dilakukan oleh (Zulhendra,2017) yang lebih membahas mengenai pendistribusian oleh BAZNAS Kota Padang kepada majelis ta'lim binaan yang diperuntukkan bagi kelompok fakir miskin. Dalam penelitian Zulhendra (2017), fakir miskin berhak mendapatkan bantuan dari BAZNAS. Sebab fakir miskin juga bagian dari kelompok yang harus diberdayakan untuk memenuhi kebutuhan hidup. Berbeda dengan penelitian ini yang lebih memfokuskan bantuan yang diperuntukkan bagi siswa yang terancam putus sekolah sehingga anak-anak kota padang bisa melanjutkan pendidikan. Selanjutnya Selasi Dkk (2019) membahas mengenai Implementasi Pengelolaan Zakat Profesi Terhadap Bantuan beasiswa Pendidikan Di Kementrian Agama Kabupaten yang lebih fokus mengenai program bantuan pendidikan oleh BAZNAS yang diperuntukkan bagi para santri/santriwati yang kurang mampu. Mengingat BAZNAS merupakan lembaga pengumpulan zakat kaum muslim, maka santri/santriwati juga diperhitungkan untuk bisa menerima bantuan dari Badan Amil Zakat Nasional. Sedangkan penelitian ini diperuntukkan bagi semua tingkatan sekolah yang siswanya kurang mampu.

Disisi lain, penelitian yang dilakukan oleh Fadilah (2019) yang berkaitan dengan program yang dijalankan BAZNAS berupa program bantuan yang lebih diperuntukkan kepada masyarakat untuk pemberdayaan ekonomi melalui zakat produktif. Sedangkan penelitian ini lebih diperuntukkan bagi siswa yang berprestasi dan kurang mampu. Berbeda penelitian yang dilakukan oleh Nopriardo (2007) yang membahas mengenai mekanisme pengelolaan zakat produktif BAZNAS di Tanah Datar. Penelitian ini dalam praktiknya, zakat yang disalurkan lebih mendominasi oleh zakat konsumtif sehingga saat zakat tersebut selesai didistribusikan maka manfaat yang diterima oleh mustahik hanya bisa 
digunakan dalam kurun waktu yang singkat. Tujuan zakat tidak sekedar menyantuni orang miskin secara konsumtif. Berbeda dengan penelitian ini yang membahas bagaimana dana zakat dari BAZNAS dapat meningkatkan akses pendidikan bagi masyarakat kurang mampu. Sehingga BAZNAS Kota Padang membuat sebuah program Padang Cerdas.

Pada dasarnya program Padang Cerdas ini merupakan sebuah program dari BAZNAS yang telah ada sejak BAZNAS berdiri yakni di bidang pendidikan. Hanya saja diganti dengan nama yang disesuaikan dengan wilayah Padang. Terakhir penelitian yang dilakukan oleh Tim Dosen Ilmu Komunikasi Fakultas Dakwah dan Komunikasi UIN Suska Riau (2017) yang membahas mengenai strategi Pengelolaan Zakat berbasis pemberdayaan masyarakat miskin pada Badan Amil Zakat Nasional di Kota Pekanbaru. Dalam penelitian ini, membahas strategi dalam meningkatkan akses pendidikan bagi masyarakat kurang mampu di Kota Padang.

Program beasiswa untuk masyarakat miskin telah dijelaskan dalam UU No 20 Tahun 2003 tentang Sistem Pendidikan Nasional yang mengatakan bahwa setiap peserta didik berhak mendapatkan biaya bagi orang tuanya yang tidak mampu. Penelitian yang berkaitan dengan Program Beasiswa yang diberikan kepada masyarakat miskin sasaran utamanya adalah status sosial yang rendah (Asshodiqiyah, 2009). Syarat untuk mencairkan dana maka siswa harus bersama orang tua atau wali (Sinulingga, 2014). Agar orang tua mengetahui berapa dana yang diterima dari program tersebut. Diharapkan bagi siswa penerima beasiswa untuk bisa mempertahankan semangat dalam menempuh pendidikan. Sebab, untuk mencapai sasaran penerima bantuan ini adalah kurang mampu dan berprestasi.

Penelitian yang berkaitan tentang beasiswa yang diperuntukkan bagi masyarakat miskin telah banyak dilakukan. Namun memiliki perbedaan walaupun secara keseluruhan sudah dibahas seperti program Padang Cerdas ini khusus untuk Kota Padang. Sehingga peneliti melakukan penelitian lanjutan yaitu pelaksanaan dari program Padang Cerdas serta bagaimana bentuk pemerataan aksesnya dalam pendaftaran bagi siswa yang layak. Karena pemerataan akses ini merupakan sebuah pembangunan pendidikan dalam meningkatkan kualitas pendidikan (Suryana, 2009) serta akses pendanaan untuk mencairkan dana beasiswa.

Identifikasi masalah dalam penelitian ini adalah keterbatasan kuota beasiswa untuk tiap sekolah yaitu 5 kuota. Kemudian keterbatasan sosialisasi yang dilakukan oleh BAZNAS Kota Padang sehingga banyak sekolah yang mengabaikan informasi dari surat edaran dari BAZNAS Kota Padang. Hasilnya banyak sekolah yang tidak terdaftar dalam beasiswa Padang Cerdas.

Penelitian ini dilakukan karena mengingat masalah pendidikan secara keseluruhan disebabkan oleh faktor pembiayaan. Sehingga angka putus sekolah masih tinggi. Dalam hal ini BAZNAS Kota Padang turut 
memberikan solusi untuk mengatasi permasalahan tersebut. Seperti pengadaan program Beasiswa yang diberikan kepada anak yang berhak mendapatkannya. Solusi yang ditawarkan oleh BAZNAS Kota Padang dalam meningkatkan akses pendidikan bagi masyarakat kurang mampu terbatas karena hanya memberikan masing-masing sekolah 5 kuota padahal masih banyak yang membutuhkan beasiswa ini. Selain itu dari program yang telah dibuat harus ada aktor pendukungnya seperti kelompok sasaran pihak sekolah. Namun masih ada sekolah yang kurang memperhatikan sehingga sekolah tidak terdaftar dalam program beasiswa.

\section{METODE PENELITIAN}

Metode yang digunakan dalam penelitian ini adalah metode kualitatif. Menurut Bodgan dan Taylor dalam Basrowi (2008) menyatakan metodologi kualitatif merupakan prosedur penelitian yang dapat menghasilkan data deskriptif berupa kata-kata ataupun lisan dari orang yang diamati sesuai dengan penelitian ini yang membahas tentang pelaksanaan program yang akan menggambarkan secara rinci tentang permasalahan yang berkaitan dengan pelaksanaan program yang dirancang oleh BAZNAS Kota Padang. Informan penelitian ini yaitu kepala bidang pendistribusian selaku pihak yang menangani masalah Program Padang Cerdas. Kemudian pihak sekolah selaku kelompok sasaran dalam program Padang Cerdas, siswa penerima bantuan Padang Cerdas serta orang tua dari siswa penerima bantuan yang dianggap paham mengenai Program tersebut.
Lokasi penelitian dalam penelitian ini yaitu di Badan Amil Zakat (BAZNAS) Kota Padang sebagai lokasi utama. Kemudian SDN 06 Surau Gadang, SMPN 33 Padang dan MAN 2 Padang yang merupakan pendukung dari program Padang Cerdas. Proses pengumpulan data menggunakan beberapa teknik yaitu pertama wawancara terstruktur dan tidak terstruktur. Kedua yaitu observasi atau non-partisipan untuk melihat kondisi lokasi kediaman orang tua untuk menguji kelayakan anaknya mendapatkan beasiswa Padang Cerdas sekaligus melakukan wawancara. Ketiga mengumpulkan data dengan dokumentasi yaitu berupa kumpulan foto yang mendukung penelitian ini.

Teknik analisis data yang digunakan adalah reduksi data yaitu merangkum hasil wawancara dan observasi yang dianggap penting yang berkaitan dengan pelaksanaan Program Padang Cerdas. Data yang diperoleh melalui wawancara, observasi dan dokumentasi disajikan dan disimpulkan untuk menjawab permasalahan penelitian tentang pelaksanaan Program Padang Cerdas.

\section{HASIL DAN PEMBAHASAN}

Pelaksanaan Program Padang Cerdas oleh BAZNAS Kota Padang

Pelaksanaan Program Padang Cerdas telah diatur dalam PERBAZNAS Pasal 4 ayat 1 tentang pendistribusian zakat dibidang pendidikan yang dapat diberikan dalam bentuk biaya pendidikan baik secara langsung dan tidak langsung. Program Padang Cerdas merupakan sebuah program yang diluncurkan oleh BAZNAS kota Padang yang berupa bantuan beasiswa 
yang diberikan untuk anak-anak yang terancam putus sekolah. Program ini bertujuan untuk memotivasi siswa agar bisa bersekolah seperti anak pada umumnya. Syarat untuk menerima beasiswa ini yaitu siswa harus beragama islam dan dengan tingkat ekonomi yang rendah. Dalam pelaksanaan yang dilakukan oleh BAZNAS Kota Padang, peneliti membagi 2 komponen dalam pelaksanaan program diantaranya:

\section{Tabel 1}

Komponen Pelaksanaan Program Padang Cerdas

\begin{tabular}{|c|c|c|}
\hline No & Aspek & $\begin{array}{c}\text { Deskripsi } \\
\text { pencapaian }\end{array}$ \\
\hline 1. & $\begin{array}{l}\text { Sosialisasi } \\
\text { yang } \\
\text { dilakukan } \\
\text { oleh } \\
\text { BAZNAS } \\
\text { Kota Padang }\end{array}$ & 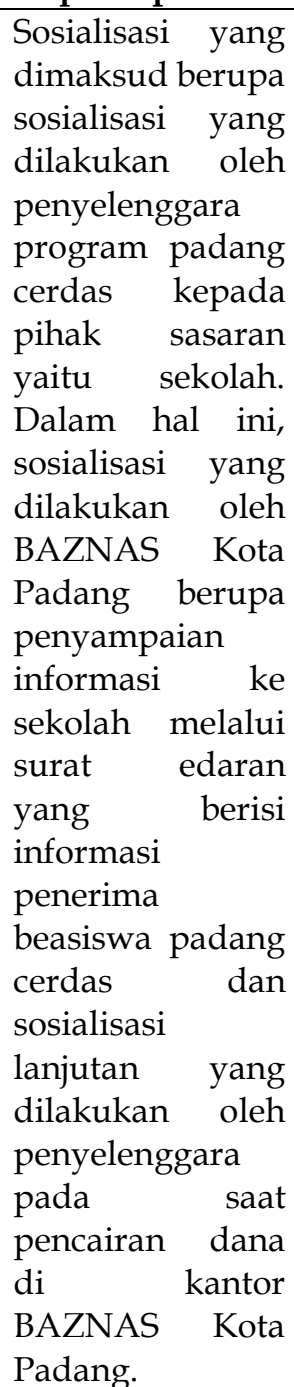 \\
\hline 2. & $\begin{array}{l}\text { Pemetaan } \\
\text { target }\end{array}$ & $\begin{array}{ll}\text { BAZNAS Kota } \\
\text { Padang }\end{array}$ \\
\hline
\end{tabular}

\begin{tabular}{|l|l|}
\hline & $\begin{array}{l}\text { melaksanakan } \\
\text { program padang } \\
\text { cerdas } \\
\text { menargetkan } \\
\text { untuk penerima } \\
\text { beasiswa padang } \\
\text { cerdas sebanyak } \\
5 \text { siswa tiap } \\
\text { sekolah dan } \\
\text { siswa tersebut } \\
\text { harus memenuhi } \\
\text { kritria yang telah } \\
\text { ditetapkan oleh } \\
\text { BAZNAS Kota } \\
\text { Padang seperti } \\
\text { siswa yang } \\
\text { tergolong kurang } \\
\text { mampu dan } \\
\text { memiliki prestasi } \\
\text { di sekolah. }\end{array}$ \\
\hline
\end{tabular}

\section{Pendanaan Beasiswa Padang Cerdas}

Dana beasiswa Padang Cerdas yang disumbangkan secara keseluruhan berasal dari dana zakat yang telah terkumpul di kantor BAZNAS Kota Padang. Pada tahun 2018 BAZNAS Kota Padang memperoleh dana sebesar Rp. 23.663.715.269. Sebanyak 20\% dari dana tersebut disumbangkan untuk pegawai BAZNAS Kota Padang. Sedangkan selebihnya digunakan untuk biaya program program yang ada.

Pendanaan dalam hal ini berupa anggaran dana yang diterima oleh penerima Beasiswa Padang Cerdas. Dana yang dikeluarkan untuk program ini sebesar 1,5 Miliar. Masing masing dana tiap tingkatan berbeda. Tingkat SD sebesar Rp. 600.000,tingkat SMP sebesar Rp.800.000,- dan tingkat MA sebesar Rp. 1.000.000,dengan pemberian dalam bentuk uang tunai. Pemberian secara tunai dianggap sebuah mekanisme yang bagus karena sekaligus memberikan sosialisasi lanjutan bagi penerima 
Journal of Civic Education (ISSN: 2622-237X)

beasiswa ini. Beasiswa ini diterima tiap 1 kali dalam setahun.

Berikut rincian penerima beasiswa Padang Cerdas tahun 2018 tiap tingkatan sekolah:

Tabel 2

Jumlah Penerima dan Jumlah Dana Program Padang Cerdas 2018

\begin{tabular}{|r|l|l|l}
\hline NO & $\begin{array}{l}\text { TINGKAT } \\
\text { SEKOLAH }\end{array}$ & $\begin{array}{l}\text { JUMLAH } \\
\text { PENERIMA }\end{array}$ & JUMLAH (UANG) \\
\hline 1. & SD & 1.800 orang & Rp, $1.080 .000 .000 ;$ \\
\hline 2. & SMP/MTS & 500 orang & $\mathrm{Rp}, 400.000 .000 ;$ \\
\hline 3. & SMA/MI & 50 orang & $\mathrm{Rp}, 50.000 .000 ;$ \\
\hline & Jumlah & $\mathbf{2 . 3 5 0}$ orang & $\mathbf{R p}, \mathbf{1 . 5 3 0 . 0 0 0 . 0 0 0}$ \\
\hline
\end{tabular}

Mekanisme pencairan dana yaitu sebelumnya BAZNAS pernah melibatkan pihak bank sebagai pendukung masalah pendanaan Program Padang Cerdas. Namun, pada kenyataannya tidak sesuai dengan apa yang diharapkan oleh penyelenggara. Karena proses pendaftaran saja sudah memakan waktu lama dan dari pihak orang tua penerima akan sering ke bank untuk pencairan dana. Padahal dana yang dikeluarkan oleh pihak bank hanya sebagian.

Pemerataan Akses Pelaksanaan Program Padang Cerdas

Akses pendaftaran yang dimaksud adalah sekolah yang terdaftar dalam beasiswa padang cerdas. Dalam pelaksanaan Program Padang Cerdas secara keseluruhan seluruh tingkatan sekolah telah mendapatkan beasiswa. Namun yang menjadi persoalan adalah beberapa sekolah yang tidak terdaftar. Karena pihak sekolah tidak mengirimkan data siswa yang berhak mendapatkan beasiswa ke kantor BAZNAS Kota Padang. Hal ini merupakan kelalaian pihak sekolah yang tidak ikut
Volume 2 No. 52019

berpartisipasi dalam mendaftaran siswanya ke kantor BAZNAS Kota Padang dan mengabaikan surat edaran dari BAZNAS untuk mengirimkan data siswa yang berhak mendapatkan beasiswa Padang Cerdas.

Berikut data sekolah yang tidak terdaftar dalam beasiswa padang cerdas di kantor BAZNAS Kota Padang:

Tabel 3

\begin{tabular}{|l|l|c|}
\hline No & \multicolumn{1}{|c|}{ Kecamatan } & $\begin{array}{c}\text { Jumlah sekolah tidak } \\
\text { terdaaftar }\end{array}$ \\
\hline 1. & Kuranji & 3 \\
\hline 2. & Padang timur & 5 \\
\hline 3. & Padang barat & 3 \\
\hline 4. & Padang utara & 2 \\
\hline 5. & Padang selatan & 3 \\
\hline 6. & Pauh & 2 \\
\hline 7. & Bungus & 2 \\
\hline 8. & Lubuk begalung & 6 \\
\hline 9. & Koto tangah & 18 \\
\hline 10. & Nanggalo & 4 \\
\hline 11. & Lubuk kilangan & 4 \\
\hline & JUMLAH & 52 \\
\hline
\end{tabular}

\begin{tabular}{c|lc}
\multicolumn{2}{|c}{ Data SMP yang tid ak Terdaftar Program Pad ang Cerd as } \\
\hline No & \multicolumn{1}{|c}{ Kecamatan } & $\begin{array}{c}\text { Jum lah sekolah tid ak } \\
\text { terdaftar }\end{array}$ \\
\hline 1. & Kuranji & 3 \\
\hline 2. & Padang timur & 5 \\
3. & Padang barat & 3 \\
4. & Padang utara & 2 \\
\hline 5. & Padang selatan & 1 \\
\hline 6. & Pauh & 2 \\
7. & Bungus & 1 \\
8. & Lubuk begalung & - \\
\hline 9. & Koto tangah & 7 \\
\hline 10. & Nanggalo & 2 \\
11. & Lubuk kilangan & 1 \\
& JUMLAH & 27 \\
\hline
\end{tabular}

\begin{tabular}{c|l}
\hline \multicolumn{2}{|c}{ Data MAMAN yang tid ak Terdaftar Program Pad ang } \\
\multicolumn{1}{|c}{ Cerdas } \\
\hline No & \multicolumn{1}{|c}{ Nam a sekolah } \\
\hline 1. & MAS PP Thawalib \\
\hline 2. & MAN 3 Padang \\
3. & MA Islam 1 Padang \\
4. & MA Perguruan 1 siteba \\
\hline \multicolumn{2}{|c}{ (sumber: BAZNAS Kota Padang) }
\end{tabular}


Berdasarkan data di atas maka peneliti dapat menyatakan bahwa pelaksanaan Program Padang Cerdas secara keseluruhan belum merata. Hal ini disebabkan bahwa kurangnya partisipasi sekolah dalam menyukseskan program yang telah dibuat oleh BAZNAS Kota Padang. Ini dibuktikan dengan pihak sekolah tidak mengirimkan data siswa yang berhak mendapatkan beasiswa Padang Cerdas.

\section{SIMPULAN}

Pelaksanaan Program Padang Cerdas terdiri dari 2 komponen. Pertama, bagaimana sosialisasi yang dilakukan oleh BAZNAS Kota Padang kepada pihak sasaran yaitu sekolah dan bagaimana BAZNAS memetakan target bagi penerima beasiswa ini. Disini peneliti dapat menyimpulkan bahwa sosialisasi yang dilakukan oleh penyelenggara sudah dijalankan dengan baik. Sosialisasi yang dilakukan berupa sosialisasi melalui surat edaran yang dikirimkan ke tiap sekolah. Kemudian ada sosialisasi lanjutan yang dilakukan oleh pihak penyelenggara program pada saat pencairan dana di kantor BAZNAS Kota Padang. Selain itu mengenai target yang dirancang oleh penyelenggara program ialah hanya menargetkan kuota 5 siswa tiap sekolah. Penyelenggara menargetkan bahwa penerima beasiswa Padang Cerdas harus memiliki kriteria yang telah ditetapkan yakni berasal dari keluara dengan ekonomi rendah namun memiliki prestasi akademik.

Terkait dengan akses pendanaan telah sesuai dengan peraturan yang telah ditetapkan oleh BAZNAS Kota Padang. BAZNAS menyumbangkan dana sebesar Rp 1,5
Miliar untuk program Padang Cerdas. Sumber dana berasal dari dana zakat yang telah terkumpul di kantor BAZNAS Kota Padang. Dana ini diberikan untuk masing masing tingkatan sekolah berbeda beda jumlah dana yang diterima tiap siswa. Terdapat beberapa sekolah yang tidak terdaftar dalam beasiswa Padang Cerdas. Hal ini dikarenakan pihak sekolah tidak menyerahkan berkas atau tidak mendaftarkan siswa yang berhak mendapatkan bantuan beasiswa Padang Cerdas. Hal ini menujukkan bahwa pihak sekolah kurang menanggapi surat edaran dari BAZNAS Kota Padang mengenai program beasiswa Padang Cerdas. Sehingga sekolah mengabaikan dan tidak berpartisipasi dalam menyukseskan program yang telah dibuat oleh BAZNAS Kota Padang.

\section{DAFTAR PUSTAKA}

Basrowi, Suwandi. (2008). Memahami penelitian kulalitatif. Jakarta. Rineka cipta

Fadilah, Hani Noor. 2019. Pengelolaan zakat di BAZNAS Kota Tangerang Selatan untuk usaha prodktif dalam pemberdayaan ekonomi umat. UIN Syarif Hidayatullah. Jakarta

Nopriardo, W. (2007). Mekanisme pengelolaan zakat produktif pada Badan Amil Zakat Nasional Tanah Datar. (Jurnal Ekonomi dan Bisnis Islam)Volume 1, Nomor 2, JuliDesember 2016

Ramdhani, A., \& Ramdhani, M. A. (2016). Konsep Umum Pelaksaan Kebijakan Publik. Jurnal Publik, 1-12.

Selasi, D., \& Wahyudin, M. (2019). Implementasi Pengelolaan Zakat Profesi Terhadap 
Bantuan Beasiswa Pendidikan

Di Kementrian Agama

Kabupaten Cirebon ( Studi

Kasus Pada BAZNAS

Kabupaten Cirebon ) Abstrak, 3(1), 22-37.

Sinulingga, R. (2014). Implementasi Program Bantuan Siswa Miskin Bagi Siswa Sma Negeri Di Kota Binjai, 7(April).

Sudarsana, I. K. (2016). Pemikiran Tokoh Pendidikan Dalam Buku Lifelong Learning: Policies, Practices, And Programs (Perspektif Peningkatan Mutu Pendidikan Di Indonesia). Jurnal Penjaminan Mutu, 2(2), 44.

Suryana, S. (2009). permasalahan pendidikan dalam perspektif pembangunan pendidikan

Tim Dosen Jurusan Ilmu Komunikasi. (2017). Strategi Pengelolaan Zakat Berbasis Pemberdayaan Masyarakat Miskin Pada AmiL Zakat Nasional (BAZNAS) Kota Pekan Baru. UIN Suska Riau. Jurnal Risalah, Vol. 28, No. 2

UU No. 23. Tahun 2003. Tentang Sistem Pendidikan Nasional Zulhendra, J., Hukum, F., \& Padang, U. T. (2017). Kajian pendistribusian zakat oleh BAZNAS kota padang kepada majlis taklim binaan ditinjau dari hukum islam, 5, 1-15 